\title{
TELAAH FAKTOR SOSIAL DEMOGRAFI TERHADAP KESETUJUAN MASYARAKAT PADA RENCANA PENGEMBANGAN HTR DI KPHP GEDONG WANI
}

\section{(STUDY ON DEMOGRAPHIC FACTORS SOCIAL DEVELOPMENT PLANS ON COMMUNITY OF AGREEMENT HTR IN KPHP GEDONG WANI)}

\author{
Wirna Ariani Pulungan'), Samsul Bakri ${ }^{2}$, dan Rudi Hilmanto ${ }^{2)}$ \\ ${ }^{1)}$ Mahasiswa Jurusan Kehutanan Fakultas Pertanian Universitas Lampung \\ ${ }^{2)}$ Dosen Jurusan Kehutanan Fakultas Pertanian Universitas Lampung \\ Jl. Soemantri Brojonegoro No. 1 Bandarlampung \\ Arianiwirnapulungan@yahoo.co.id
}

\begin{abstract}
ABSTRAK
Sejak tahun 2007 Kementerian Kehutanan menggulirkan kebijakan pemanfaatan hutan produksi berbasis masyarakat melalui Peraturan Menteri Kehutanan (Permenhut) Nomor. P.23/Menhut-II/2007 tanggal 25 Juni 2007 tentang Tata Cara Permohonan Ijin Usaha Pemanfaatan Hasil Hutan Kayu dalam Hutan Tanaman Rakyat dalam Hutan Tanaman, yang kemudian digantikan dengan Permenhut Nomor.P.55/Menhut-II/2011. Kebijakan pembangunan HTR ini membuka akses kepada masyarakat untuk mengelola hutan produksi secara legal. Tujuan dari penelitian ini yaitu untuk mengetahui pengaruh faktor demografi faktor sosial budaya dan aksesbilitas terhadap program Hutan Tanaman Rakyat (demografis, sosial budaya, properti, aksesibilitas). Penelitian ini dilaksanakan di Desa Sinar Rejeki, Desa Karang Rejo, Desa Budi Lestari, dan Desa Tri Mulyo Kecamatan Tanjung Bintang Kabupaten Lampung Selatan Provinsi Lampung pada bulan Agustus 2014. Penelitian ini telah membuktikan bahwa tingkat kesetujuan responden terhadap rencana pengembangan Hutan Tanaman Rakyat Tingkat kesetujuan responden terhadap rencana pengembangan Hutan Tanaman Rakyat dipengaruhi secara nyata oleh kelompok variabel properti: (a) yang mempunyai kendaraan peluangnya 2,14 kali lebih besar dari pada yang tidak punya (b) namun yang pengusaan lahan kering maupun lahan basah lebih luas 1 ha akseptabilitas menjadi 0,001 kali. Dan kelompok variabel demografi, sosial budaya dan aksesbilitas tidak berpengaruh nyata terhadap akseptabilitas rencana pengembangan Hutan Tanaman Rakyat.
\end{abstract}

Kata kunci: demografi masyarakat, faktor sosial, kawasan KPHP

\section{ABSTRACT}

Since 2007 the Ministry of Forestry rolling the policy on the use of community-based forest production through the Minister of Forestry (Minister) Number. P.23 / Menhut-II / 2007 dated June 25, 2007 on Procedures for Application Permit Utilization of Wood in Forest Plantation in Plantation Forest, which was later replaced by Regulation Nomor.P.55 / Menhut-II / 2011. HTR development policy is open access to the public to manage production forests legally. The aim of this study is to determine the influence of demographic factors socio-cultural factors and accessibility of the program Plantation Forests (demographic, social, cultural, property, accessibility). This research was conducted in the village of Sinar Rejeki, Karang Rejo village, Budi Lestari Village, and the village of Tanjung Bintang Subdistrict Tri Mulyo South Lampung regency in Lampung province in August 2014. This study has shown that the level of agreement of respondents to the Forest Plantation development plan Level of agreement of respondents to plan the development of Forest Plantation influenced significantly by group variable property: (a) the vehicle has 2.14 times 
greater odds than on who does not have (b) but that the procurement of dry land and wet land over an area of 1 ha of acceptability be 0,001 times. And group demographic variables, social, cultural and accessibility do not significantly affect the acceptability of Plantation Forest development plan.

Keywords: community demographics, social factors, KPHP region

\section{PENDAHULUAN}

Peraturan pemerintah Nomor 3 Tahun 2008 tentang tata hutan dan penyusunan rencana pengelolaan hutan, serta pemanfaatan hutan. Peraturan ini kemudian dijabarkan melalui Peraturan Menteri Kehutanan (Permenhut) Nomor P.23/Menhut-II/2007. Permenhut Nomor P.5/Menhut-II/2008 tentang tata cara permohonan ijin usaha pemanfaatan hasil hutan kayu pada hutan tanaman rakyat dalam hutan tanaman PP Nomor 6 Tahun 2007.

Hutan Tanaman Rakyat (HTR) merupakan kebijakan yang digulirkan oleh departemen kehutanan pada awal tahun 2007, yaitu berupa pemberian hak akses kepada masyarakat sekitar untuk membangun hutan tanaman di kawasan hutan negara (Amrullah, 2013). Tanaman pada hutan produksi yang dibangun oleh kelompok masyarakat untuk meningkatkan potensi dan kualitas hutan produksi dengan menerapkan silvikultur dalam rangka menjamin kelestarian sumber daya hutan. Kelompok masyarakat yang dimaksud selanjutnya dijabarkan dalam Permenhut Nomor 23/Menhut II/2007 sebagai perorangan atau koperasi. Untuk itu maka perlu dilakukan penelitian tentang telaah faktor sosial demografi masyarakat yang berdomisili di empat desa hutan dalam kawasan KPHP Gedong Wani Provinsi Lampung yang berperan terhadap kesetujuan rencana pengembangan HTR..

\section{Tujuan Penelitian}

Tujuan dari penelitian ini untuk mengetahui pengaruh faktor demografi, faktor sosial budaya dan aksesbilitas terhadap program Hutan Tanaman Rakyat (demografis, sosial budaya, properti dan aksesibilitas).

\section{METODE PENELITIAN}

\section{Lokasi dan Waktu Penelitian}

Penelitian ini dilaksanakan di Desa Sinar Rejeki, Desa Karang Rejo (Kecamatan Jati Agung), Desa Budi Lestari, dan Desa Trimulyo (Kecamatan Tanjung Bintang) Kabupaten Lampung Selatan Provinsi Lampung pada bulan Agustus 2014. Pemilihan responden dilakukan secara Purposive Sampling.

\section{Objek dan Alat Penelitian}

Objek pada penelitian ini adalah masyarakat didalam kawasan KPHP Gedong Wani Kecamatan Jati Agung dan Tanjung Bintang Kabupaten Lampung Selatan Provinsi Lampung, khususnya yang berdomisili di empat desa, Desa Sinar Rejeki, Desa Karang Rejo, Desa Budi Lestari, dan Desa Trimulyo. Adapun peralatan yang digunakan antara lain: alat tulis, kalkulator, komputer, panduan wawancara atau kuisioner, dan kamera.

\section{Jenis Data dan Sumber Data}

Data yang digunakan dalam penelitian ini adalah data primer dan data sekunder. Data primer diperoleh dari wawancara langsung dengan responden di lokasi penelitian melalui kuisioner. Data primer yang dikumpulkan meliputi karakteristik sosial demografi masyarakat 
di empat desa dalam kawasan KPHP Gedong Wani yang berperan terhadap kesetujuan rencana pengembangan HTR.

Data sekunder yang digunakan dalam penelitian ini diperoleh dari instansi pemerintah di lokasi penelitian. Data sekunder yang dikumpulkan meliputi data yang menyangkut informasi mengenai rencana program pengembangan HTR, serta monografi desa tempat penelitian.

\section{Metode Pengambilan Sampel}

Metode penarikan contoh di lakukan secara stratifikasi di lanjutakan dengan penarikan contoh secara insidental. Strata pertama, yaitu pemilihan sampel desa-desa, yang dilakukan secara sengaja terhadap empat desa dari 38 desa yang ada di Kawasan KPHP Gedong Wani. Keempat desa yang di pilih di maksudkan untuk mencapai keefisienan dalam pelaksanaan penelitian, yaitu 2 Desa Sinar Rejeki dan Karang Rejo terdapat dalam Kecamatan Jati Agung, dan 2 Desa lainnya Desa Budi Lestari dan Tri Mulyo terdapat dalam kecamatan Tanjung Bintang.

Pada strata ke dua juga dilakukan wawancara secara sengaja kepada pamong desa, selanjutnya pada strata ketiga dilakukan secara insidental ke rumah-rumah warga. Di mulai dari yang terdekat dengan rumah pamong desa dilanjut sampai 30 responden. Dalam wawancara digunakan kuisioner seperti yang terdapat pada lampiran.

\section{Analisis Data}

Ada 2 jenis analisis data yang telah dilakukan yaitu analisis statistik deskriptif dan analisis statistik inferensial. Hasil analisis statistik deskriptif disajikan pada Tabel 1, sedangkan untuk statistik inferensial dilakukan dengan menggunakan model regresi Ordinal yang dijabarkan pada sub-sub.

\section{Variabel dan Definisi Operasional}

Variabel definisi operasional simbol yang dipergunakan dalam model dan skala pengukuran di sajikan dalam tabel 1. 
Tabel 1. Variabel dan Definisi Operasional.

\begin{tabular}{|c|c|c|c|c|}
\hline No. & Variabel & Simbol & Definisi Opersional & Skala Pengukuran \\
\hline 1 & $\begin{array}{l}\mathrm{Y}=\text { adanya program } \\
\text { hutan tanaman } \\
\text { rakayat }\end{array}$ & $\mathrm{Y}$ & $\begin{array}{lcc}\text { Jumlah orang } & \text { setuju } \\
\text { dengan adanya } & \text { hutan } \\
\text { tanaman rakyat } & \end{array}$ & $\begin{array}{l}\text { Dummy } \\
\mathrm{SS}=\text { sangat setuju } \\
\mathrm{TS}=\text { tidak setuju } \\
\mathrm{KS}=\text { kurang setuju }\end{array}$ \\
\hline 2 & Jenis kelamin & KLM & $\begin{array}{l}\text { Perbedaan antara } \\
\text { perempuan dengan laki- } \\
\text { laki secara biologis } \\
\text { sejak seseorang lahir. }\end{array}$ & $\begin{array}{l}\text { Dummy } \\
1=\text { pria } \\
0=\text { lainnya }\end{array}$ \\
\hline 3 & Umur (th) & UMR & $\begin{array}{l}\text { Usia responden sejak } \\
\text { lahir sampai dengan } \\
\text { menjadi responden } \\
\text { dinyatakan dalam tahun. }\end{array}$ & Rasio \\
\hline 4 & Status & STATUS & Petani dan pamong desa & $\begin{array}{l}\text { Biner } \\
1=\text { petani } \\
0=\text { pamong }\end{array}$ \\
\hline 5 & Pekerjaan & PRKJN & $\begin{array}{l}\text { Pekerjaan utama } \\
\text { responden. }\end{array}$ & $\begin{array}{l}\text { Biner } \\
1=\text { petani } \\
0=\text { lainnya }\end{array}$ \\
\hline 6 & $\begin{array}{l}\text { Lama tinggal di } \\
\text { kecamatan }\end{array}$ & LTDKC & $\begin{array}{l}\text { Lama tinggal (tahun) } \\
\text { responden di dalam } \\
\text { kecamatan }\end{array}$ & Rasio \\
\hline 7 & Pemilikan hp & PHP & $\begin{array}{l}\text { Pemilikan alat } \\
\text { komunikasi }\end{array}$ & $\begin{array}{l}\text { Biner } \\
1=\text { punya } \\
0=\text { tidak }\end{array}$ \\
\hline 8 & Kendaraan & KNDRN & Alat transfortasi & $\begin{array}{l}\text { Biner } \\
1=\text { punya } \\
0=\text { tidak }\end{array}$ \\
\hline 9 & $\begin{array}{l}\text { Luas pengusaan lahan } \\
\text { kering (ha) }\end{array}$ & LPLK & Ladang/kawasan & Rasio \\
\hline 10 & $\begin{array}{l}\text { Luas penguasaan lahan } \\
\text { basah (ha) }\end{array}$ & LPLB & Ladang/kawasan & Rasio \\
\hline 11 & $\begin{array}{l}\text { Jarak lahan kepusat desa } \\
(\mathrm{km})\end{array}$ & JLKPD & Jarak/akses jalan & Rasio \\
\hline 12 & KPDLN & KPDLN & Kepedulian & $\begin{array}{l}\text { Biner } \\
1=\text { membantu } \\
0=\text { tidak }\end{array}$ \\
\hline
\end{tabular}

Sumber : Data Penelitian Tahun 2014

\section{HASIL DAN PEMBAHASAN}

\section{Hasil Penelitian dan Pembahasan}

\section{Statistik Deskriptip Responden Penelitian}

Dari setiap responden yang diambil sejumlah 120 semuanya berumur sekitar dari 28 81 tahunan. Hal ini menunjukkan bahwa kawasan KPHP Gedong Wani dilaksanakan oleh petani pada usia produktif yaitu dapat dikerjakan secara optimal dengan mencurahkan tenaga kerja fisik yang tersedia (Nurhasikin, 2013). 
Tabel 2. Identitas Responden (Kepala Keluarga).

\begin{tabular}{clrll}
\hline No. & Statistik deskriptif & Umur (thn) & Pendidikan & Pekerjaan Utama \\
\hline 1. & Max & 81 & SMP & Petani \\
2. & Min & 30 & SD & Petani \\
3. & Modus & 45 & 0 & Petani \\
\hline
\end{tabular}

Sumber: Data Penelitian Tahun 2014

Tingkat pendidikan responden rata-rata adalah lulusan SMP yang berarti bahwa masyarakat di Kawasan KPHP Gedong Wani memenuhi wajib belajar 9 tahun. Kawasan KPHP Gedong Wani terdiri 4 Desa dari 2 Kecamatan yaitu Desa Sinar Rejeki, Desa Karang Rejo terdiri dari Kecamatan Jati Indah dan Desa Budi Lestari, Tri Mulyo terdiri dari Kecamatan Tanjung Bintang. Dari keempat desa tersebut terdapat responden 120 rata-rata petani.

Table 3. Umur Responden di Empat Desa KPHP Gedong Wani.

\begin{tabular}{ccrr}
\hline No. & Umur Petani (Tahun) & & Frekuensi \\
\hline 1. & & $28-40$ & 48 \\
2. & $41-55$ & 56 \\
3. & & $55-81$ & 25 \\
\hline & & 120 \\
\hline
\end{tabular}

Sumber: Data Penelitian Tahun 2014

Table 4. Status Sosial Responden di Empat Desa KPHP Gedong Wani.

\begin{tabular}{clrr}
\hline No. & & Status Sosial & Frekuensi \\
\hline 1. & Petani & & 104 \\
2. & Pamong desa & 16 \\
\hline & Total & & 120 \\
\hline
\end{tabular}

Sumber: Data Penelitian Tahun 2014

Jumlah responden yang berusia 28-45 tahun adalah sebanyak 65 selanjutnya yang memiliki usia 51-81 berjumlah 55 tahun.

\section{Hasil pemodelan Regresi Log-Likelihot dengan Uji Gald}

Hasil Analisis Regresi Log-Likelihood Optimasi parameter $=100,464$ dengan menggunakan Uji Gald 22,306 dengan P-Value 0,034. Nilai Uji Gald tergolong besar dan ini bersesuaian dengan $P$-value yang dihasilkan yang mempunyai makna bahwa variabel respon atau jawaban dari KK responden (Y) dapat secara baik diprediksi atau diduga berdasarkan ke 11 variabel prediktor tersebut. dengan melihat $P$-valuenya yaitu 0,034 (atau $=3,4 \%<5 \%$ ). Maknanya bahwa kalau ada $100 \mathrm{KK}$ yang mau diduga respon atau jawaban atas pertanyaan tentang kesetujuannya pada rencana program HTR yang ditawarkan, maka dapat diprediksi dengan menggunakan ke-11 variabel tadi bahwa ada sebanyak 96 (dibulatkan ke bawah) responden yang diprediksi secara tepat dan hanya sebanyak $4 \mathrm{KK}$ yang meleset. Artinya model yang di Uji atau diterapkan dapat dipandang handal dalam prediksi calon peminat Hutan Tanaman Rakyat. Dengan demikian model tersebut secara matematik dapat diungkapkan sebagai berikut: 


$$
\begin{aligned}
L n=\frac{\mathrm{P}(1)}{1-\mathrm{P}(0)}= & -3,00360-2,18354+0,899045[\mathrm{STTS}] \mathrm{i}+0,0081164[\mathrm{UMUR}] \mathrm{i}- \\
& 0,508224[\mathrm{KLM}] \mathrm{i}+0,683418+[\mathrm{PKJRN}] \mathrm{i}+0,0086729[\mathrm{LTDKC}] \mathrm{i}+0,0194287[\mathrm{KP} \\
& \mathrm{DLN}] \mathrm{i}+0,341610[\mathrm{PHP}] \mathrm{i}+0,759935[\mathrm{KNDRN}] \mathrm{i}-5,91141[\mathrm{LPLK}] \mathrm{i}- \\
& 6,42760[\mathrm{LPLB}] \mathrm{i}+0,317329[\mathrm{JLKPD}] \mathrm{i}
\end{aligned}
$$

Adapun pengaruh dari positif atau pun negatif serta besarnya pengaruh masing masing variabel penjelas ataupun variabel prediktor terhadap respon jawaban dari KK yang akan

\begin{tabular}{|c|c|c|c|c|c|c|c|}
\hline Predictor & Coef & SE Coef & $\mathrm{Z}$ & $\mathrm{P}$ & Odds Ratio & Lower & Upper \\
\hline Const(1) & $-3,00360$ & 1,66734 & $-1,80$ & 0,072 & & & \\
\hline Const(2) & $-2,18354$ & 1,65722 & $-1,32$ & 0,188 & & & \\
\hline \multicolumn{8}{|l|}{ Demografis } \\
\hline STTS SOSIAL & 0,899045 & 0,783029 & 1,15 & 0,251 & 2,46 & 0,53 & 11,40 \\
\hline UMUR & 0,0081164 & 0,0160101 & 0,51 & 0,612 & 1,01 & 0,98 & 1,04 \\
\hline KLM & $-0,508224$ & 0,424809 & $-1,21$ & 0,232 & 0,60 & & \\
\hline PRKJN & 0,683418 & 0,682680 & 1,00 & 0,317 & 1,98 & 0,52 & 7,55 \\
\hline LTDKC & 0,0086729 & 0,0228823 & 0,38 & 0,705 & 1,01 & 0,96 & 1,05 \\
\hline \multicolumn{8}{|l|}{ Sosial_Budaya } \\
\hline KPDLN & 0,0194287 & 0,141805 & 0,14 & 0,891 & 1,02 & 0,77 & 1,35 \\
\hline PHP & 0,341610 & 0,451943 & 0,76 & 0,450 & 1,41 & 0,58 & 3,41 \\
\hline \multicolumn{8}{|l|}{ Properti } \\
\hline KNDRN & 0,759935 & 0,391893 & 1,94 & 0,051 & 2,14 & 0,99 & 4,61 \\
\hline LPLK & $-5,91141$ & 3,04451 & $-1,94$ & 0,051 & 0,01 & 0,01 & 1,06 \\
\hline LPLB & $-6,42760$ & 3,15740 & $-2,04$ & 0,042 & 0,01 & 0,01 & 0,79 \\
\hline \multicolumn{8}{|l|}{ Aksesibilitas } \\
\hline JLKPD & 0,317329 & 0,272290 & 1,17 & 0,244 & 1,37 & 0,81 & \\
\hline
\end{tabular}
diprediksi untuk masing-masing variabel penjelas dapat diuraikan pada Tabel 5.

Tabel 5. Ringkasan hasil optimasi parameter model yang berperan terhadap kesetujuan rencana pengembangan hutan tanaman rakyat Logistic Regression Table.

Sumber: Hasil Penelitian 2014.

Test that all slopes are zero: $\mathrm{G}=22,306, \mathrm{DF}=12, P$-Value $=0,034$

\section{Pengaruh Beberapa Variabel Demografi}

\section{a. Status Sosial}

Variabel status sosial (STTS) mempunyai koefesien 0,899 positif menaikkan jawaban KK responden dari tidak setuju menjadi setuju atau setuju menjadi sangat setuju. Adapun besar pengaruh tersebut adalah bahwa yang berstatus petani mempunyai peluang 2,46 kali (odds ratio) dari pamong desa. Artinya lebih bebas menyatakan pendapat terhadap adanya program HTR. Fakta ini memberikan indikasi bahwa kepentingan petani lebih bersesuaian dibandingkan dengan kepentingan pamong desa terhadap rencana pengembangan HTR. Dalam konteks ini pamong desa mempunyai hubungan struktural terhadap atasanya yaitu Camat atau Bupati sehingga bebas dalam berpendapat (Arini, 2011). Namun pengaruh positif dari variabel prediktor STTS tersebut tidak nyata sebagaimana ditunjukkan oleh $P$-Value yang $0,251=(25,1 \%>10 \%)$.

\section{b. Umur}

Variabel umur mempunyai koefesien 0,008 positif, yang bermakna jika umur bertambah 1 tahun maka peluang untuk meningkatkan dari tidak setuju menjadi setuju atau setuju menjadi sangat setuju bersifat positif. Adapun besar pengaruh tersebut adalah mempunyai peluang 1,01 (odds ratio) kali semula. Dalam penelitian ini artinya petani umur bertambah 1 tahun lebih tua akan lebih positif kesediannya dari pada yang lebih muda, 
walaupun begitu pengaruh variabel umur ini tidak nyata sebagai mana ditunjukan oleh nilai P-Value $0,612(61,2 \%>10 \%)$. Adapun petani masih tergolong usia produktif yaitu antara 1564 tahun mendomiasai responden penelitian (Nurhatikin, 2013).

\section{c. Jenis Kelamin}

Koefesien hasil optimasi parameter bernilai negatif $-0,508$ artinya KK yang berjenis kelamin perempuan lebih cenderung terhadap rencana pengembangan Hutan Tanaman Rakyat. Dalam hal ini bahwa peluang KK laki-laki untuk tidak setuju menjadi setuju atau setuju menjadi sangat setuju peluang hanya 0,60 kali KK wanita seperti ditunjukan oleh odds ratio nya. Penomena ini mengindentifikasi bahwa perempuan selalu dianggap berstatus lajang atau sendiri. Perempuan tidak mendapat tunjangan keluarga, serta jaminan sosial untuk suami dan anak. Oleh karena, perempuan sangat sulit memperoleh promosi jabatan karena selalu ditempatkan di posisi yang lebih rendah dari laki-laki (Sinta, 2010). Walaupu begitu pengaruh negatif dari variabel prediktor KLMN tersebut tidak nyata sebagai mana ditunjukkan oleh nilai $P$-Value yaitu $(0,232 \%>10 \%)$.

\section{d. Pekerjaan}

Koefesien untuk variabel pekerjaan [PRKJN] diperoleh 0,683 positif dengan odds ratio 1,98 dengan P-Value nya0,317. Artinya yang perkerjaannya petani mempunyai peluang untuk setuju menjadi sangat setuju atau tidak setuju adalah sebesar 1,98 kali yang pekerjaannya sebagai buruh tani, sebagaimana ditunjukkan oleh nilai odds rationya. Namun perbedaan ini tidak nyata dengan nilai $P$-Value yaitu $=0,317=(31,7 \%>10 \%)$. Setiap tenaga kerja mempunyai hak dan kesempatan yang sama untuk memperoleh pekerjaan dan penghidupan yang layak tanpa membedakan jenis kelamin, suku, ras dan agama, sesuai dengan minat dan kemampuan tenaga kerja yang bersangkutan. Baik bagi pengusaha wajib memberikan perlakuan yang sama tanpa diskriminasi kepada pekerja (Ahmad, 2008).

\section{e. Lama tinggal di kecamatan}

Variabel lama tinggal di kecamatan (tahun) mempunyai koefesien 0,008 positif artinya lama tinggal dikecamatan makin mempunyai respon positif. Dalam ini yang lebih lama tinggal 1 tahun dalam kecamatan peluang untuk setuju menjadi setuju atau setuju menjadi sangat setuju (odds ratio) 1,01 kali yang lama tinggalnya lebih rendah dari 1 tahun. Namun pengaruh positif dari variabel prediktor lama tinggal dikecamatan (tahun) tersebut tidak nyata sebagaimana ditunjukkan oleh nilai $P$-Value yaitu $=0,705=(70,5 \%>10 \%)$.

\section{Pengaruh Beberapa Variabel Sosial Budaya}

a. Kepedulian Pada Sesama (Solidaritas)

Optimasi parameter terhadap variabel kepedulian (solidaritas) (KPDLN) memberikan hasil koefisien 0,019 odds ratio 1,02 dan nilai $P$-Value yaitu $0,891=(89,1 \%>10 \%)$. Dalam penelitian ini variabel KPDLN dimaksudkan untuk membedakan kelompok masyarakat yang punya kepedulian sosial yang lemah terhadap kelompok yang punya kepedulian yang kuat. Ternyata yang punya kepedulian sosial yang kuat mempunyai peluang yang lebih besar untuk setuju ataupun sangat setuju terhadap rencana pengembangan HTR. Dalam hal ini yang kepeduliannya kuat peluang 1,02 beda dengan yang kepedulianya lemah, seperti ditunjukkan oleh odds ratio nya. Namun pengaruh ini tidak nyata sebagaimana ditunjukkan oleh nilai $P$ Value yaitu $=0,891=(89,1 \%>10 \%)$.

\section{b. Alat komunikasi}

Variabel pemilikan telepon genggam (HP) mempunyai koefesien 0,431 positif menaikkan jawaban dari yang mempunyai kepemilikan telepon genggam (HP) dari tidak 
setuju menjadi setuju atau setuju menjadi sangat setuju. Adapun besar pengaruh tersebut adalah yang memiliki telepon genggam mempunyai peluang 1,41 (odds ratio) dari yang tidak memiliki telpon genggam. Hal ini disebabkan oleh meningkatnya akses komunikasi dan informasi yang diperoleh masyarakat tentang manfaat dari HTR. Namun pengaruh positif dari variabel prediktor PHP tersebut tidak nyata sebagaimana ditunjukkan oleh nilai $P$-Value yaitu $0,450=(45,0 \%>10 \%)$. Hal ini menunjukkan bahwa alat komunikasi berperan penting terhadap keberhasilan pertanian, telepon genggam hand phone merupakan penunjang untuk mendapatkan informasi secara cepat, dan pemanfaatan teknologi informasi dan komunikasi di daerah pedesaan bertujuan untuk meningkatkan kualitas hidup masyarakat yang tinggal di pedesaan secara signifikan (Fathoni, 2010).

Alat komunikasi menujukkan nilai yang tidak berbeda nyata. Hal ini disebabkan karena petani belum memaksimalkan alat komunikasi yang ada untuk mencari informasi yang terkait dengan lahan pertanian yang petani kelola atau komunikasi terhadap keluarga.

\section{Pengaruh Beberapa Variabel Properti}

a. Pengaruh Kepemilikan Kendaraan

Koefesien positif 0,759935. Artinya pengaruh positif terhadap skema pengembangan HTR. Pengaruh ini nyata seperti ditunjukan P-Value yang 0,051 $(<10 \%)$. Dalam hal ini yang punya kendaraan lebih propospolitif terhadap penerimaan (Akseptabiltas) pada skema Hutan Tanaman Rakyat yaitu peluang akseptabilitas tersebut menjadi 2,14 dibanding yang tidak punya kendaraan baik itu dari sikap tidak setuju menjadi setuju atau dari setuju menjadi sangat setuju. Umumnya yang punya kendaraan punya mobilitas ke luar lebih besar, dengan begitu punya peluang berjenjang lebih besar pula untuk selanjutnya dapat mempunyai informasi yang lebih luas termaksud informasi yang positif sifatnya terhadap rencana skema pengembangan Hutan Tanaman Rakyat. Bagi masyarakat pedesaan, alat transportasi akan terasa sangat penting untuk menghubungkan mereka ke kota atau ke daerah lain dalam memenuhi segala kebutuhannya. Jarak desa dengan kota yang jauh akan menjadi penghambat terhadap pertumbuhan desa. Tanpa adanya alat tranportasi semuanya akan terasa sangat sulit dalam perjalanan ke suatu tempat yang jaraknya jauh. Karena Perkembangan transportasi sekarang membawa dampak kehidupan yang lebih baik (Rofik, 2012).

\section{b. Luas lahan kering}

Koefesien hasil optimasi parameter bernilai negatif 5,91141 yang berarti yang punya luas penguasaan lahan kering LPLK lebih luas dan cenderung tidak setuju terhadap skema pengembangan Hutan Tanaman Rakyat, dalam hal ini reponden yang punya luas penguasaan lahan kering LPLK bertambah 1 ha maka peluang nya akan berkurang menjadi 0,01 kali semula baik yang tidak setuju menjadi setuju atau menjadi sangat setuju, Artinya dengan adanya luasan kepemilikan penguasaan lahan kering itu merupakan bahwa responden menginginkan penguasaan yang dia pikir lebih baik menjadi hak milik. Karena semakin tinggi kepadatan penduduk suatu desa, ternyata luas lahan pertanian yang terkonversi makin kecil. Semakin tinggi kepadatan petani pemilik pada suatu desa ternyata akan mengurangi konversi lahan pertanian (Agus, 2009). Hal ini menunjukkan bahwa apapun jenis lahan yang dimiliki petani mereka setuju dengan adanya program Hutan Tanaman Rakyat. Penguasaan luas lahan memang sangat mempengaruhi besarnya pendapatan bagi petani karena tanah merupakan salah satu faktor produksi pertanian (Yudha, 2011). Pengaruh positif dari variabel prediktor LPLK tersebut nyata sebagai mana ditunjukkan oleh nilai $P$-Value yaitu $0,052=(05,2 \%>10 \%)$. 


\section{c. Luas lahan basah}

Koefesien hasil optimasi parameter bernilai negatif 6,42760 yang berarti yang punya luas penguasaan lahan basah LPLB lebih luas dan cenderung tidak setuju terhadap skema pengembangan Hutan Tanaman Rakyat, dalam hal ini reponden yang punya luas penguasaan lahan basah LPLB bertambah 1ha maka peluang nya akan berkurang menjadi 0,01 kali semula baik yang tidak setuju menjadi setuju atau menjadi sangat setuju, Artinya dengan adanya luasan kepemilikan penguasaan lahan kering itu merupakan bahwa responden menginginkan penguasaan yang dia pikir lebih baik menjadi hak milik.

Semakin tinggi kepadatan penduduk suatu desa, ternyata luas lahan pertanian yang terkonversi makin kecil. Semakin tinggi kepadatan petani pemilik pada suatu desa ternyata akan mengurangi konversi lahan pertanian (Agus, 2009). Hal ini menunjukkan bahwa apapun jenis lahan yang dimiliki petani mereka setuju dengan adanya program Hutan Tanaman Rakyat. Penguasaan luas lahan memang sangat mempengaruhi besarnya pendapatan bagi petani karena tanah merupakan salah satu faktor produksi pertanian. Jika petani mempunyai lahan yang luas, maka akan lebih besar pendapatannya dari pada yang tidak memiliki lahan yang sempit (Yudha, 2011). Pengaruh positif dari variabel prediktor LPLB tersebut nyata sebagai mana ditunjukkan oleh nilai $P$-Value yaitu $0,042=(05,2 \%>$ $10 \%)$.

\section{d. Pengaruh Jarak Lahan Kepusat Desa}

Variabel jarak lahan ke pusat desa mempunyai koefesien 0,317 positif menaikkan jawaban dari yang memiliki pengusaan lahan dari pusat ke desa dari tidak setuju menjadi setuju atau setuju menjadi sangat setuju, adapun besar pengaruh tersebut adalah yang memiliki lahan dekat degan pusat desa ( $\leq 2,5 \mathrm{~km}$ ) mempunyai peluang 1,37 (odds ratio) dari yang tidak memiliki pengusaan lahan jauh dari pusat desa $(>2,5 \mathrm{~km})$. Artinya rakyat yang memiliki pengusaan lahan dekat dengan pusat desa lebih mendukung terhadap program HTR. Namun pengaruh positif dari variabel prediktor JLKPD tersebut tidak nyata sebagai mana ditunjukkan oleh nilai $P$-Value yang $=0,244=(24,4 \%>10 \%)$. Semakin jauh jarak pengusaan lahan dengan kepusat desa, Maka semakin besar konversi pengusaan lahan pertanian yang terjadi (Agus, 2009).

\section{KESIMPULAN DAN SARAN}

\section{Kesimpulan}

Adapun kesimpulan yang dapat di buat dari hasil penelitian ini adalah: Tingkat kesetujuan responden terhadap rencana pengembangan Hutan Tanaman Rakyat dipengaruhi secara nyata oleh kelompok variabel properti: (a) yang mempunyai kendaraan peluangnya 2,14 kali lebih besar dari pada yang tidak punya (b) namun yang pengusaan lahan kering maupun lahan basah lebih luas 1 ha akseptabilitas menjadi 0,001 kali dan, Kelompok variabel demografi, sosial budaya dan aksesbilitas tidak berpengaruh nyata terhadap akseptabilitas rencana pengembangan Hutan Tanaman Rakyat.

\section{Saran}

Disarankan untuk melakukan penelitian serupa di kawasan KPHP lainnya yang mempunyai permasalahan serupa seperti di KPHP Muara Dua, KPHP Way Terusan ataupun KPHP di luar Provinsi Lampung. Dan disarankan pula untuk melakukan penelitian serupa pada Skema (Hkm) Hutan Kemasyarakatan di KPHL baik di dalam maupun di luar Provinsi Lampung. 


\section{DAFTAR PUSTAKA}

Adhelia, T. 2007. Analisis faktor-faktor yang mempengaruhi pendapatan tenaga kerja wanita dari sektor informal dikota makasar. Skripsi. Universitas Hasanudin. Makasar.

Adhi, Y. 2011. Pengaruh trans formasi lahan pertanian menjadi perkebunan kelapa sawit terhadap tingkat kesejahteraan petani dikecamatan babulu kabupaten penajam paser utara provinsi kalimantan timur. Skripsi. Universitas Hasanudin. Makasar.

Agus, 2009. Dampak konversi lahan pertanian terhadap kesejahteraan petani dan perkembangan wilayah studi kasus didaerah bandung utara. Jurnal Agro Ekonomi. 25 (2):207-219.

Ahmad, 2008. Pengaruh timbal-balik antara kepuasan kerja dengan kepuasan keluarga dan komitmen kerja serta dampaknya terhadap prestasi kerja dan karier dosen. Fakultas Ekonomi Universitas Brawijaya Malang. Jurnal Pengaruh kenerja. 7(2):45-56.

Arini, 2012. Peranan kepala desa dalam menyelesaikan sengketa pembagian waris menurut hukum adat di desa sidorejo kecamatan pagelaran kabupaten malang. Skripsi. IPB. Bogor

Dapartemen Kehutanan. 2011. Peraturan Menteri Kehutanan Nomor:P.55/MenhutII/2011.Permenhut P.31/Menhut-11/2013 Tentang tata cara permohonan izin usaha pemanfaatan hasil hutan kayu pada hutan tanaman rakyat dalam hutan tanaman. Laporan penelitian. Jakarta

Fathoni, 2010. Strategi implementasi teknologi informasi dan komunikasi untuk meningkatkan kualitas hidup masyarakat pedesaan di Indonesia. Jurnal Komunikasi, volume 20(5): 201-209.

Nurhasikin, 2013. Penduduk usia produktif dan ketenagakerjaan. Artikel. Diakses tangga 21 November 2014. http://kepri.bkkbn.go.id/Lists/Artikel/DispForm.aspx?ID=144.

Purwanto,S, E Wati dan S,A Cahyono. 2004. Kelembagaan untuk mendukung pengembangan hutan rakyat produktifitas tinggi. Puslitbang Bioteknologi dan pemuliaan Tanaman, Yogyakarta.

Rofik, A. 2012. Pengaruh-Perkembangan-Teknologi.html. Edisi Khusus. Buku. YramaWidya. Bandung

Sinta, 2010. Perspertif sejarah status kawasan hutan, konflik dan negosiasi di Sumber Jaya Lampung Barat Provinsi Lampung. Lampung. Jurnal Agrivita. 26(1):126-537.

Yudha. 2011. Pengaruh trans formasi lahan pertanian menjadi perkebunan kelapa sawit terhadap tingkat kesejahteraan petani dikecamatan babulu kabupaten panajam paset utara propinsi kalimantan timur. Skripsi. Universitas Hasanudin. Makasar.

Yulianto. S, E. W. S, A. Cahyono. 2013. Kelembagaan untuk mendukung pengembangan hutan rakyat produktifitas tinggi. Puslitbang bioteknologi dan pemuliaan tanaman. Yogyakarta.

Yusran, 2005. Analisis performansi dan pengembangan hutan kemiri rakyat di kawasan pegunungan bulusaraung sulawesi selatan. Disertasi tidak diterbitkan. Bogor: Program Pascasarjana Institut Pertanian Bogor. 